\title{
Discussion on Damages of Karst to Roadbed and Its Countermeasures
}

\author{
Lincheng Wang \\ The Second Engineering Co., Ltd., the Third Engineering Group of China Railway, Shijiazhuang, China \\ Email: mlbsabc@sina.com
}

How to cite this paper: Wang, L.C. (2018) Discussion on Damages of Karst to Roadbed and its Countermeasures. Open Journal of Civil Engineering, 8, 58-63. https://doi.org/10.4236/ojce.2018.81005

Received: February 13, 2018

Accepted: March 17, 2018

Published: March 20, 2018

Copyright (C) 2018 by author and Scientific Research Publishing Inc. This work is licensed under the Creative Commons Attribution International License (CC BY 4.0).

http://creativecommons.org/licenses/by/4.0/

\begin{abstract}
Because of the long-term dissolution of water, the formation of karst caves and fissures in rock formations are called karst. In Karst area, deformation and water damage are the main forms of karst damage to subgrade. Uneven settlement of embankment and instability of subgrade are the concrete manifestations of karst roadbed diseases. Therefore, considering the scale effect of karst, the concrete treatment measures of karst roadbed should be put forward and the principle of prevention and treatment of "dredging, crossing, reinforcing and blocking" should be followed, based on the characteristics of various karst forms, such as section funnel, depression, karst cave, solution crack and karst spring.
\end{abstract}

\section{Keywords}

Karst, Scale Effect, Uneven Settlement, Treatment

\section{Introduction}

Karst is a generic term, which is the chemical dissolution of soluble rock, such as limestone and dolomite, dissolved in water, and accompanied by mechanical actions to form groove, fissure, caves, as well as a series of phenomena and effects, such as cavitation caused by cave roof collapse. Because there are karst caves, dissolution fractures and hidden rivers in the karst area, the ground deformation and foundation collapse may occur under the weight of rock body, which will affect the safety of road structures. Due to the movement of ground water, inundation and other sudden accidents may appear in the structure of the site or the foundation [1].

In the western part of our country, karst topography is widely distributed. Combined with geological structures, its genesis, scale, mechanical characteristics and evolution law are all different, which makes the construction of roads 
more complicated. Highway construction faces the challenge of karst geological hazards. If the bad geological treatment such as karst is careless, it will bring many problems. For example the occurrence of the karst ground collapse accident in some places brought negative impacts on progress, quality and cost of the projects. This paper will put forward concrete measures of roadbed treatment in karst area with the background of a specific project, by discussing the formation mechanism, distribution, morphology and development characteristics of karst.

\section{Introduction of the Project}

The section of a highway is the tectonic erosion of the low mountain landform. The terrain is undulating and the mountain is rounded. Vegetation is relatively developed, covering a thin layer. Bedrock is mostly bare. Natural slope is slower, mainly made of carbonate of Triassic. The low-lying areas are mostly cultivated land. The karst landform development mainly includes karst trough valley, karst hill, depression, funnel, sink hole, current and so on. Groundwater is dominated by vertical discharge. Surface springs are rare. The route is made of igneous and metamorphic rocks, such as pyrolith and metamorphite. The amount of water varies greatly with season, climate and terrain, and the underground aquifer has weak ability to keep water. It belongs to temperate continental humid climate. Rainfall is concentrated in the zone and the rainfall is heavy. It has frozen cold phenomenon in winter [2].

\section{The Basic Rules of Karst Development}

Karst refers to the geological processes with main chemical effects and auxiliary mechanical effects that the groundwater and surface water which have a corrosion force on soluble rocks, such as the carbonate and limestone. The process of karst chemistry is influenced by the concentration and pressure of water, temperature, precipitation, atmospheric pressure, rock composition and geological structures. Its forms mainly include karst cave, sink hole, karst ditch, dissolving trough, gap, dark river, stone bud, karst depression, karst spring, funnel and stalactite. The solubility and permeability of rock, the dissolution of water and its fluidity in the rock mass are the basic conditions for karst development. The more acidic the water, the faster the circulation, the more precipitation, the higher the temperature, the more karst development. The karst development of joints, fissures, fractures, folds, uplifts, fault zones and subsidence zones have significant effects [3].

Triassic thick layered carbonate rocks are widely distributed in the area of the project. Geological structure is the channel of surface water and groundwater flow which forms various faults and folds. The perennial river and seasonal streams are distributed among them, with four distinct seasons. It has abundant rainfall and the surface vegetation is well covered. Under the joint action of lithology, geomorphology, structure and hydrodynamic conditions, the karst in this section developed well. 
Most karst caves and water holes have no water. But during the rainy season, it becomes the site of karst water and runoff and excretory channel. The section of K256 + $215-\mathrm{K} 256+450$ karst pipeline is more prominent. Although karst water and modern underground river have little influence on the highway. However, the rock karst gap in the line is unfavorable to the stability of the foundation and the roadbed bearing layer.

In the area, during the rainy season, the slopes of both sides of the river are affected by a large area of surface water and the rise and fall of the underground river. Its water level and discharge of river water will directly cause potential trouble to roadbed. Therefore, the section is roughly divided into underground runoff drainage area and atmospheric precipitation recharge area. There are also two regional intersecting situations.

In the section of $\mathrm{K} 259+500-\mathrm{K} 260+000$, it is characterized by underground runoff and excretion. The horizontal flow is the main form of underground water flow in the region. The karst form is characterized by its horizontal development, which manifests the development of karst level pipeline, the well plane extends and goodd Karst groundwater connectivity. If the roof of the horizontal pipe produces a roof, it will lead to a massive ground collapse [4].

In the section of $\mathrm{K} 267+500-\mathrm{K} 261+000$, groundwater recharge is the main feature. Groundwater is mainly supplied by atmospheric precipitation. Groundwater is dominated by vertical flow. Correspondingly, karst state is dominated by vertical development, which manifests that the water hole, the ditch and the trough are relatively developed. The plane extension is generally small, but the vertical direction extends more deeply. That is, the depth of the sink hole, the ditch and the sink is large. Geological radar and high density resistivity are used for comprehensive geophysical exploration. It is found that 60 karst depressions, funnels, karst caves, water holes and other karst areas along the whole road section need to be treated.

The comprehensive detection results of karst structures are shown in Table 1.

\section{The Scale Effect of Karst Form}

Although the disease of karst roadbed can be attributed to deformation and water damage, however, different structural sizes of the same karst form have different effects on the same subgrade structure. That means the karst structure has the scale effect. The scale effect of karst structure is mainly reflected in the following aspects [5].

1) The surface of stone bud, stone forest, dissolve ditch, dissolve ridge is rough. The difference between the strength and deformation characteristics of the roadbed is formed by the funnel, the dissolution depression, the dissolution valley and the dissolution. The existence and flow of water in shaft, sink hole, karst cave and sink hole can cause uneven settlement of embankment. However, when the length and area of these karst structures are different, the effects of causing uneven settlement are different. When these parameters are larger than 
Table 1. Comprehensive detection results of karst structures.

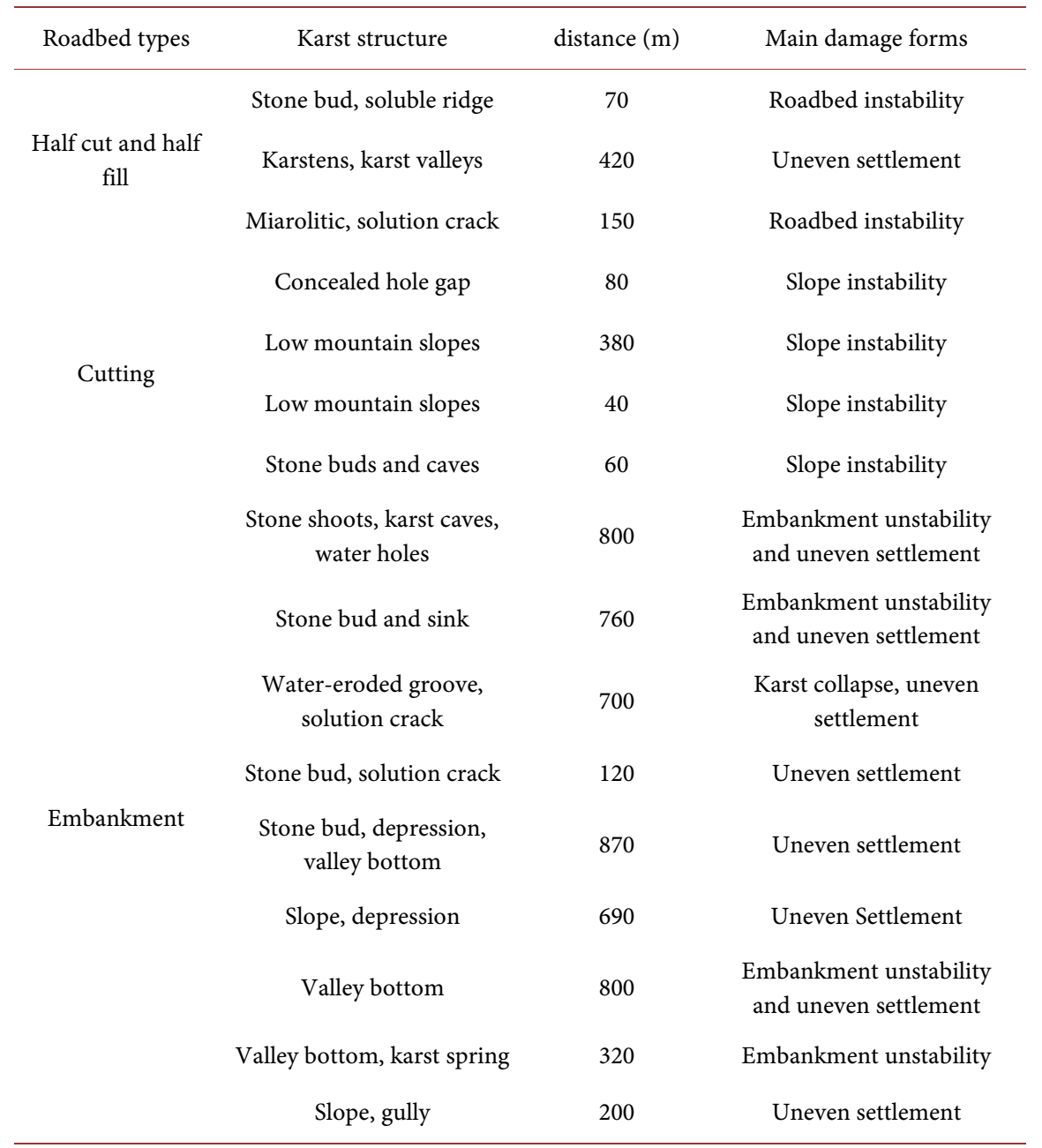

an order of magnitude compared to the subgrade structure size, the roadbed performance will be compromised. When these parameters are smaller than an order of magnitude compared to the subgrade structure size, the effects could be negligible.

2) The existence and flow conditions of surface water and groundwater are changed when the surface water and groundwater are caused by the dissolution of the ditch, the ridges, the funnel, the dissolution depression, the dissolution valley, the gap, the shaft, the sink hole, the cave, etc. In that condition, the roadbed stability problem will occur. The collapse of the karst cave and the sink will also affect the stability of the roadbed. When these karst structures are different in size, distribution density, space range, burial depth and thickness, etc., the effects on the stability of subgrade are different. That is when these parameters are larger than an order of magnitude compared to the subgrade structure size, the roadbed will be destabilized. And when these parameters are smaller than an order of magnitude compared to the subgrade structure size, the effects could be negligible [6]. 


\section{The Main Treatment Measures of Karst Subgrade}

\subsection{Packing}

As to a small and dry hole in the cut, the cave on the roadbed could be filled with schist or gravel. The upper part is made of slurry stone. The surface of the cave wall is removed before masonry. The side of the wall is chipped into steps. The thickness of the masonry must form a rigid body, and it should be no less than 0.5 meters. The top is flush with the roadbed, and covers the hole around 50 $100 \mathrm{~cm}$.

When there is not much karst under the roadbed, its roof is thicker and the rock is hard and complete, which does not affect driving safety, it is generally not handled. As to a lighter and smaller dry bare cave, the hole should be sealed with slurry or concrete after filling it with dry stones [7].

\subsection{Grouting}

As to the loose accumulation of rock and gravel that is deep in the hole, due to the big clearing workload and not easy to blast, the slurry should be taken to cement it. The grouting materials mainly include pure cement slurry, cement slurry, cement, yellow mud slurry, cement-water glass slurry, cement-aggregate slurry and chemical slurry, etc.

The column chart could be used to understand caves, water leakage and soil cover. If the core is broken, the hole is deep and the hole is leaking, the water needs to be tested at the bottom of the hole, according to which, the method of grouting could be decided, such as the casing position, pressure or self-flow, whether need double-liquid grouting, first filling the bottom and then filling up part. The height of the slurry could be measured in 20 to 30 minutes after shutdown to determine the level of casing lift. Each hole is raised three or four times and will stop when it comes to the surface of the soil.

\subsection{Crossing}

It is deep and slender in the subgrade cave, underground river and other places, the roof can be blasted open with reinforced concrete cover or bridge due to its poor construction conditions and not easy to fill.

When the karst of the subgrade base often waters or seasonally waters, it is very easy to cause subgrade to collapse, sink, inundation or slurry. We can intercept the water upstream. If we can't intercept, we can use reinforced concrete to cover plate, bridge culvert, drainage hole and other buildings. If the flow is not large, we can also fill the stones to the embankment.

\subsection{Desludging}

Removing surface water or ground water near the embankment, and preventing the continued erosion of the soluble rock by water, the karst water on the cutting slope could be used as slope seepage or hanging ditch according to its flow size. 
Water can be introduced into the side ditch or bridge culvert.

\section{References}

[1] Gutierrez, F., Parise, M., De Waele, J. and Jourde, H. (2014) A Review on Natural and Human-Induced Gaohazards and Impacts in Karst. Earth-Science Reviews, 138, 61-88. https://doi.org/10.1016/j.earscirev.2014.08.002

[2] White, W.B. (1993) Analysis of Karst Aquifers. In: Alley, W.M., Ed., Regional Ground-Water Quality, Van Nostrand Reinhold, New York, 471-489.

[3] Li, Y.J. (2005) Stability Evaluation and Treatment of Karst Subgrade in Expressway. Hunan Communication Science and Technology, No. 1, 23-25.

[4] Wang, J.X., Yang, L.Z. and Liu, D. (2000) Study on the Risk of Subgrade Collapse in Low Mountain Rock in Karst. Journal of Geological Disasters and Prevention in China, No. 2, 37-39.

[5] White, W.B. (2002) Karst Hydrology: Recent Developments and Open Questions. Engineering Geology, 65, 85-105. https://doi.org/10.1016/S0013-7952(01)00116-8

[6] Petrishev, V.P., Chibilev, A.A., Akhmedenov, K.M. and Ramazanov, S.K. (2011) The Formation Features of Landscapes in the Inderskii Salt-Dome Area (Precaspian Hollow). Geography and Natural Resources, 32, 146-151. https://doi.org/10.1134/S1875372811020077

[7] Nguyet, T.M., Thanh, V.P., Hai, V.D., Roi, N.D. and Tra, D.T. (2016) Hydrogeochemical Characterization and Groundwater Quality of the Dong Giao Karst Aquifer in Tam Diep, Ninh Binh, Vietnam. Acta Carsologica, 45, 233-242. https://doi.org/10.3986/ac.v45i3.3588 